\title{
The Negative Impact of Rapid Growth of Culinary Tourism in Bandung City: Implementation of Innovative and Eco- Friendly Model Are Imperative
}

\author{
Prety Diawati ${ }^{1}$, Henry H. Loupias ${ }^{2}$ \\ ${ }^{1}$ Program Study of Corporate Management, Politeknik Pos Indonesia, Bandung, Indonesia \\ ${ }^{2}$ Faculty of Art and Literature, Universitas Pasundan, Bandung, Indonesia \\ Email : ${ }^{1}$ pretydiawati@poltekpos.ac.id, ${ }^{2}$ loupiashenry@gmail.com
}

\begin{abstract}
Bandung is known as a culinary city mainly by domestic tourists from Jakarta. The negative impact of the visit was an increased volume of garbage around $100-200$ tons / weekends. In addition, about $75 \%$ of garbage derived from styrofoam food packaging and drink plastic bottles. In order to face the problem of increasing the volume of garbage as the negative impact of culinary tourism, it is necessary to do the right solution. One effort is to innovate culinary products by developing foods that can be packed with natural materials. Innovative packaging has attractiveness and selling power. However, innovation is an effort to face a competitive market.The purpose of this study is to explain the phenomenon of culinary tourism in Bandung City. The research used descriptive methods. The research samples are culinary products and its packagings that are widely consumed by domestic tourists from Jakarta or other cities.
\end{abstract}

Keywords - Culinary tourism, Eco-friendly design, Garbage, Innovation, Packaging design.

\section{INTRODUCTION}

Bandung City known by many designations, one of them is culinary city. The culinary business shows a rapid growth. So far, Bandung City is known as one of the creative city in East Asia, fashion city, factory outlet city, and culinary city. The majority of tourists are domestic tourists who visit to Bandung City(Alamsyah and Loupias, 2018:(9). According to the Creative Economy Agency (BEKRAF) report that the culinary sector contributes Rp. 209 trillion or about 32.5\% of Gross Domestic Product (GDP) in 2016. Culinary is one of the creative economic sub sectors of a total of 15 subsectors. Exports of culinary sub-sector is ranked third, which is Rp.11.816.125 million. The figure shows that the culinary sub-sector is an important economic potential.

In Bandung City there are various kinds of culinary products such as traditional Sundanese food, Padang, Europe, China, and others. Consumers are diverse including domestic tourists. The majority of domestic tourists visiting Bandung come from Jakarta for various reasons, such as easy access from Jakarta to Bandung, food and beverage prices are cheaper than in Jakarta.

Basically, the tourism industry can provide various economic benefits for many parties, namely local governments, employers, and local communities. Positive impacts can increase the income and economy of local communities, including providing jobs in the informal sector.

According to Alamsyah and Loupias (2018) that:" The tourism sector is a significant economic potential for both local government revenue (Pendapatan Asli Daerah) as well as local community income" (Alamsyah and Loupias, 2018:3). But there is a negative impact of the growth of the tourism industry, namely the increase in the volume of garbage. According to the records of the cleanliness 
agency (Dinas Kebersihan) that the volume of garbage in Bandung City on weekends or holidays increases about 100-200 tons / day. The increase is a major problem for the tourism industry because it can lead to various direct impacts on a tourist destination, such as dirty location, bad smell, and cause various diseases. Most of the waste comes from food wrapper from styrofoam or plastic food, plastic drink bottles, coffee cups and the like. Type of non-organic garbage is about $75 \%$, which consists of garbage styrofoam and plastic that is difficult to recycle. So that cause ditches clogged and pavement flooded water. Even styrofoam and plastic waste can cause clogged streams. The problem of waste above can cause tourist destinations become less attractive to tourists, including reducing culinary consumers. However, the negative impacts of culinary tourism need to be addressed immediately, especially in reducing garbage. It is feared could cause the income of entrepreneurs and culinary sellers to decline. Actually, the problem of garbage in Bandung City is "classic" due to infrastructure owned by the government of Bandung is inadequate. Conversely, the volume of garbage continues to increase every day, especially on weekends or holidays.

Ideally, the problem of domestic tourist garbage solved together between the government, businessmen / street vendors, and public (tourists). This means not only rely on the role of the government of Bandung City, but includes the efforts of culinary entrepreneurs, restaurant and café owner to innovate products. The innovation is to develop food products and develop environmentally friendly food packaging designs. Actually, the raw materials of environmentally friendly packaging is available in Bandung and surrounding areas, such as leaves. Though traditional Sundanese food before the found in plastic materials and styrofoam - wrapped with various types of leaves. Food products wrapped in leaves are more profitable, inexpensive, hygienic and unique.

In some countries, for example in Japan there are still many traditional foods wrapped or packed with natural ingredients and designed attractively. In addition to appetizing prospective consumer also serves as an added value. Similarly, in the Netherlands, a variety of tea products are packaged attractively to serve as gifts, for example for the person who gave birth to the baby. Though the products are everyday consumer goods but with this innovation they become more attractive and increase its economic value. However, innovation is a necessity for companies in modern times without innovation a company is not able to compete: "Product innovation can also have an important effect on firm productivity, especially if it takes the form of powerful new or improved intermediate inputs"(Breakthrough Innovation and Economic Growth, 2015: 10).

\section{LITERATURE REVIEW}

\section{Global Tourism Industry}

According to Balalia that the tourism activity is mainly sustained by the private initiative, but the government plays a key role in developing the tourism... (Balalia 2011:217); Hall explains the positive impacts of tourism on the economy and poverty. The role of tourism in local economic development and poverty reduction in less developed countries has been extensively explored since 2000 (Hall 2014: 6); For many countries, international tourism has been an indispensable source of foreigncurrency earnings (Atilgan et al.2003:414).

The tourism industry is an economic potential for many countries in the world. The contribution of the tourism industry to the national economy is significant. This industry is considered the industry's fastest growth compared to other industries. From managerial perspective, tourism industry is considered as one of the fastest growing industries, ranging from business, governmental and intergovernmental organizations to tourist [6].Besides, it is a driver of progress for other sectors. Tourism becoming one of the largest and fastest growing economic sectors in the world and therefore it contitutes a key driver of socio-economic progress through export revenues, the creation of jobs and 
enterprises, and infrastructure development [14]. According to Barbosa et al. (2010), tourism - if conducted in a sustainable way - can provide an alternative for local national development by improving income levels, employment and tax revenues in the tourist receiving country [5]; The data of the tourism industry in South East Asia with over 104 million international arrivals in 2015 and an average growth of $8 \%$, South East Asia's Travel and tourism industry has incredible potential to help generate growth, create jobs, and enable regional development [13]; Tourism is a highly competitive industry, and tourism enterprise sector can no longer compete on the basis of cost alone. Therefore, promoting quality in tourism and tourist products is a priority in different tourism activities [11]. One model of the tourism industry according toUnited Nations Environment Programme and World Tourism Organization that is sustainable tourism development which refers to environmental, economic, and socio-cultural aspects calls for optimal use and protection of natural resources, assuring the respect for social and cultural characteristics of local (host) communities, cultural heritage protection, and providing socio-economic benefits for tourism stakeholders [6]; Some of the criteria of sustainable tourism as followsbe environmentally responsible; have a triple-bottom line approach (environmental, social, and economic); obtain guest satisfaction and educate tourist about environmental and social concerns [6].While Baumgartner (2013)proposes the following model:"A model relaying on the economic prosperity, protected nature, intact culture, wellbeing of local community, and staff, and visitors satisfaction in order to enable future development of tourism at a destination [6].

\section{Innovation}

There are many definitions of innovation, among others: “Innovations doesn't take place in a vacuum - it's subject to a range of internal and external influences which shape is possible and what actually emerges. In particular it needs clear strategic leadership and direction, plus the commitment of resources to make this happen. Innovation is about taking risks, about going into new and sometimes completely unexplored spaces" (Bessant \& Tidd, 2011: 551): In their opinion that this type of innovation is open innovation: "We've always known that innovation is not a solo act: successful

players work hard to build links across boundaries inside the organization and to the many external agencies who can play a part in the innovation process - suppliers, customers, sources of finance, skilled resources and of knowledge, etc. Twenty first century innovation is increasingly about open innovation, a multi player game where connections and the ability to find, form and deploy creative relationships is of the essence" (Bessant \& Tidd, 2011: 557); Furthermore, Bessant and Tidd explained that the key to innovation is people: "The key to innovation and entrepreneurship is, of course, people. And the simple challenge is how to enable them to deploy their creativity and share their knowledge to bring about change" (Bessant \& Tidd, 2011: 554). There is a new understanding of innovation as stated below: "Today, innovation capability has been seen less in terms of the ability to discover new technological, state-of the-art inventions. The literature now emphasizes the ability to exploit new technological combinations, the notion of incremental innovation and innovation without research" (The Changing Face of Innovation, 2011: 27).

In short that innovations improve the quality of life by multiplying consumers' choices. They enrich people's lives in numerous ways - making life easier, improving communications, providing new forms of entertainment, and improving health care, to name a few (Holden, 2007 : 17); Collins (1997) defined innovation can be defined as either the aplication of a new method or device; Thomas and Rhisiart (2000) state the successful exploitation of a new idea; According to Baregheh et al. (2009) states innovation is the multi-stage process whereby organizations transform ideas into new/improved products, services or processes, in order to advance, compete and differentiate themselves successfully in their marketplace (Thomas et al., 2011: 10). According to Barbosa et 
al.(2010) competitiveness is the ability to survive and achieve profitable growth in competing to develop more suitable communities (Barbe et all, 2016)

In fact, the importance of innovating for other companies is to compete. Companies that do not invest in innovation put their future at risk. Their business is unlikely to prosper, and they are unlikely to be able to compete if they do not seek innovative solutions to emerging problems (Jhon, et all, 2013). The role of innovation in the context of the global economy that innovation is a central driver of economic growth and development. Firms rely on innovation and related investments to improve their competitive edge in a globalizing world with shorter product life cycles (The Changing Face of Innovation, 2011: 23); Yuzbasiogluet al state innovation has an important role on the changing of market conditions and competitive tools, and achievement of competitve strategies (Yuzbasioglu et al.,2014:736); Schumpeter said innovation is "new ways of doing things, or unique combinations of the factors of production" and he identifies these new ways and unique combinations as the core values of firms (Yuzbasioglu et al.,2014:736).

At the same time new products development is an important capability because the environment is constantly changing. Shifts in the socio-economic field (in what people believe, expect, want, and earn) create opportunities and constraints. Legislation may open up new pathways, or close down others - for example, increasing the requirements for environmentally friendly products. Competitors may introduce new products which represent a major threat to existing market positions. In all these ways firm need the capability to respond through product innovation (Jhon, et all, 2013).

For example, a new design of car, a new incurance package for accident-prone babies and a new home entertainment system would all be examples of product innovation. And change in the manufacturing methods and equipment used to produce the car or the home entertainment system, or in the office procedures and sequencing in the insurance case, would be examples of process innovation.Sometimes the dividing line is somewhat blurred - for example, a new jet powered sea ferry is both a product and a process innovation. Services represent a particular case of this where the product and process aspects often merge - for example, is a new holiday package a product or process change?

Innovation can also take place by repositioning the perception of an established product or process in aparticular user context (Jhon, et all, 2013). Tidd and Bessant explain the notion of innovation, namely: 'product innovation' - changes in the things (products/services) which an organization offers; 'process innovation' - are changes in the ways in which they are cracked and delivered (Jhon, et all, 2013). A second form of product innovation is the introduction of new products that did not previously exist. Surveys also find that it is small and medium-sized firms in particular which innovate without conducting formal R\&D (Tiffany, 2017).

\section{RESEARCH METHODS}

This study uses qualitative research methods with the aim to describe the condition of current research object culinary tourist in Bandung City. The use of qualitative research methods for the following reasons. Qualitative researchers are concerned primarily with process, rather than outcomes or products, qualitative researchers are interested in meaning how people make sense of their lives, experiences, and their structures of the world, the qualitative researcher is the primary intrument for data collection and analysis, qualitative research involves fieldwork (Atieno, 2009: 15). Primary data is obtained through direct survey to research sites, interviews with related parties such as traders and tourists. Secondary data comes from research and literature. 


\section{RESULT AND DISCUSSION}

\section{A. Culinary Tourism Industry in Bandung City}

The development of tourism industry in Bandung City is supported by various factors, such as toll road infrastructure from Jakarta to Bandung. The toll road provides easy access for Jakarta tourists to visit Bandung on weekends and holidays. In addition, it is influenced by domestic tourists from other cities who visit Bandung City. They have encouraged the development of culinary tourism in Bandung City. Indeed, most of Jakarta's tourists aims to shop for clothing products at factory outlets. Basically, between shopping activity and culinary tourism are related. Increasing the number of domestic tourists to Bandung City as well as increasing the volume of food consumption. There are many types of food as an effort to meet those needs and most of the food is ready to eat.

In order to respond to the increase in tourist visits, there are many places to eat and drink around factory outlets. Some factory outlet locations and places to eat and drink are located on Riauw street, Dago street, Setiabudhi street, Sukajadi street (Parijs van Java), GatotSubroto street (Trans Studio Mall ) and other touristic locations.Type of culinary business such as restaurants, cafes and street vendors.They sell a variety of foods but on average sell ready-to-eat food. The food is wrapped in packs of styrofoam, thick paper or plastic container. While the drinks are also in plastic bottles or paper cup. The goal is to quickly serve, can be brought and practical use.In Japan styrofoam material is widely used for food containers such as instant noodles for practical use and cheap price. But the styrofoam food containers do not cause problems for the environment because they care about cleanliness and the environment. In addition, Japan has technology to destroy styrofoam and plastic materials.

Therefore, it is necessary to take the role of society in facing garbage problem in Bandung City. In some developing countries, the public private partnership (PPP) model is applied in addressing public interest, including garbage.In short, the problem of waste should be handled by all parties, namely the government, private entrepreneurs (owner of factory outlets, restaurants, cafes, street vendors and the public (tourists).In addition, law enforcement needs to be applied
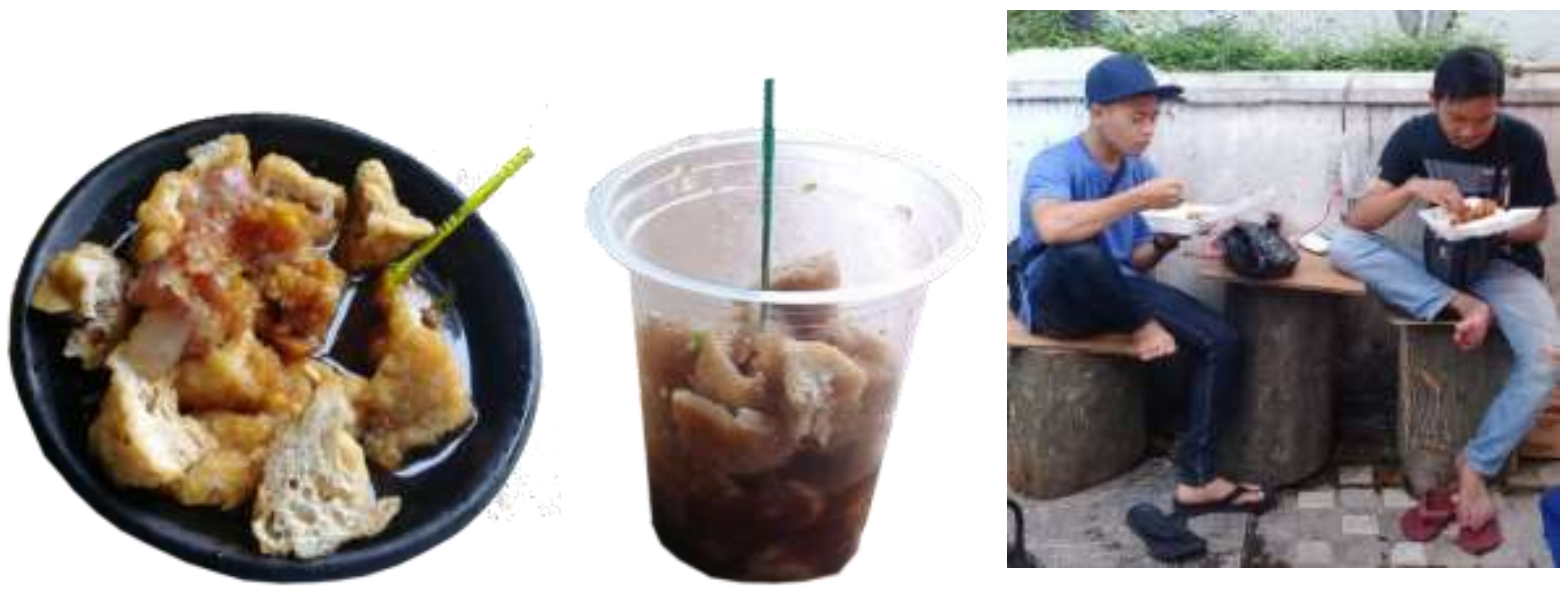

Fig. 1 (Left) Cirebon typical food TahuGejrotsold at food stall of factory outlet Heritage served with pottery plate. (Center) TahuGejrot served in plastic cups for domestic tourists. (Right) Two street vendors in Riauwstreet were eating with styrofoam food packaging. 
The impact of consumption patterns of domestic tourists and local communities has caused the volume of garbage in Bandung City increased. Of this amount about $75 \%$ is non-organic garbage, namely in the form of plastic food packaging and styrofoam, plastic drink bottle and coffee cup made of thick paper. Increasing the volume of garbage in culinary tourism destinations can cause various negative impacts, such as dirty environment, bad smell, and symptoms of disease.Therefore, the negative side of the tourism industry - especially culinary tourism - need to find the right solution by the government of Bandung. Thus a holistic approach is needed to address this issue precisely ie the ability to develop a tourism business and can reduce the negative impact of garbage.

The tourism industry is growing rapidly in many countries. In addition to having a positive impact on the national economy but there are negative impacts for tourist destinations and the environment. One impact is the deterioration of environmental quality due to air and garbage pollution. In order to overcome these problems there is a model that is considered suitable for development, namely sustainable tourism development.

\section{B. Innovative Product and Eco-Friendly Packaging Design}

The case of culinary tourism in Bandung is the occurrence of increasing the volume of garbage, including non-organic garbage that is difficult to be recycled. Many factors lead to an increase in the volume of garbage - not just limited equipment and human resources - such as low concern for hygiene among the public, both domestic and urban residents of Bandung. Therefore, it needs to be innovated so that culinary tourism can grow, still able to compete, or can create environmentally friendly products.Innovation is one of the efforts in dealing with business competition because this is a company's competitive aspect.

Basically, innovation consists of two types, namely product and process innovation. Regardingproduct innovation can be done by creating new products or improvements that already exist. However, an innovation does not have to be really new as stated by Peter F. Drucker who called "creative imitation". Understanding Drucker's theory that a creation does not have to be entirely new but utilizes the invention of others by adding something different and interesting. In the process of design and handicraft - packaging products can be classified in handicraft products - the process of "imitating" is common. At the very least, a design is influenced by the previous design. In addition, some food packaging product creations are universal in many parts of the world.

Culinary products can be developed in an innovative way, for example a food product wrapped using natural raw materials from leaves. Leaf raw materials are widely available and varied. So it can be tailored to the needs or type of food. Some traditional food products wrapped in leaves, such as Wajitor Dodol wrapped in corn leaves, Bacang wrapped with Hanjuang leaves, Lontong wrapped in banana leaves, Ketupator Kupatwrapped in coconut leaves, Buntil wrapped with papaya leaves or sweet potato. Actually packs of food and raw materials are included in the category of local wisdom. But because the development of modern technology has led to the people tend to want practical things. Anotherencouragement, is the need for increased consumer products. Product requires mass production process. So that the traditional package is considered less practical, the process is long or some natural raw materials difficult to obtain. 

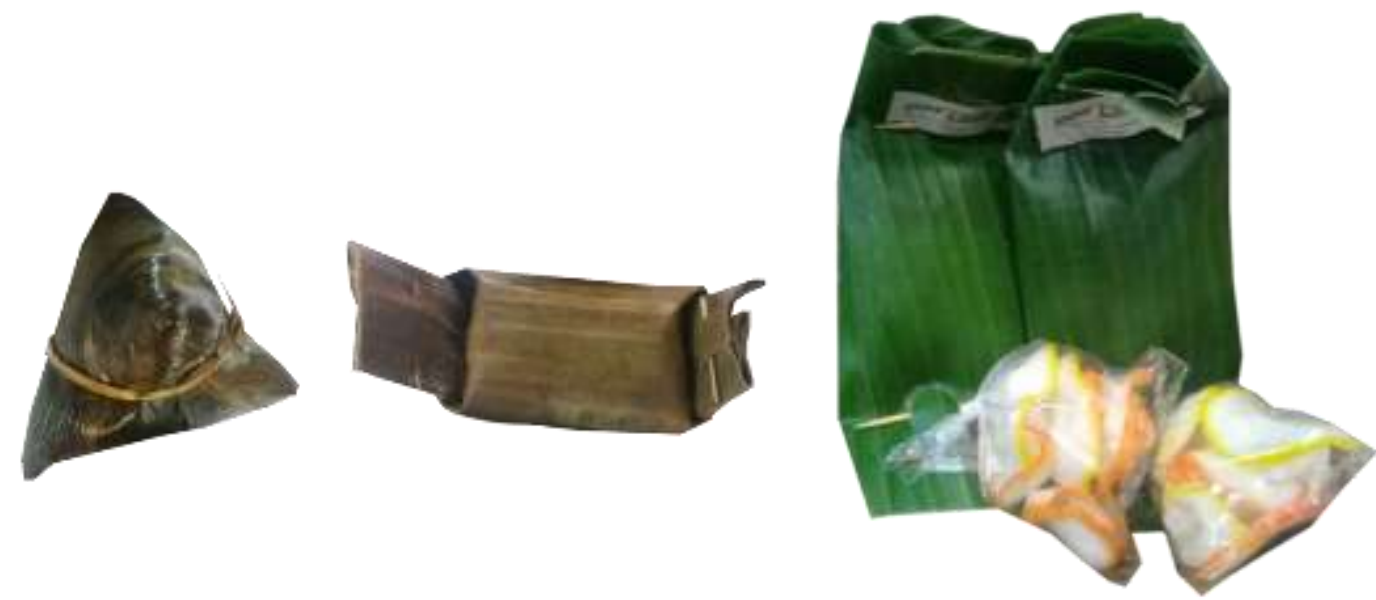

Fig. 2 (Left) Bacang wrapped with Hanjuangleaves. (Center) Lontong or Leupeut (Sundanese) wrapped with banana leaves. (Right) Rice wrapped with banana leaves. These are eco-friendly packaging but it need to be developed to be more attractive and have prestige for the consumer.

Generally, culinary products for the consumption of domestic tourists have different requests such as limited quantities and good quality. Therefore, the use of natural raw materials by traditional production means is possible. It can even be more interesting than mass production for tourists.Through innovation allows the diversification of products to increase its kind and can provide many choices to tourists. Innovation can also increase buying interest of consumers (tourists) and the selling value of their products. For example, in general, traditional Japanese food is packed with interesting, whether the form of food or wrap. In the Netherlands, tea products are packaged as gifts, such as births, with these innovations making the price of the product expensive and attracting consumers.
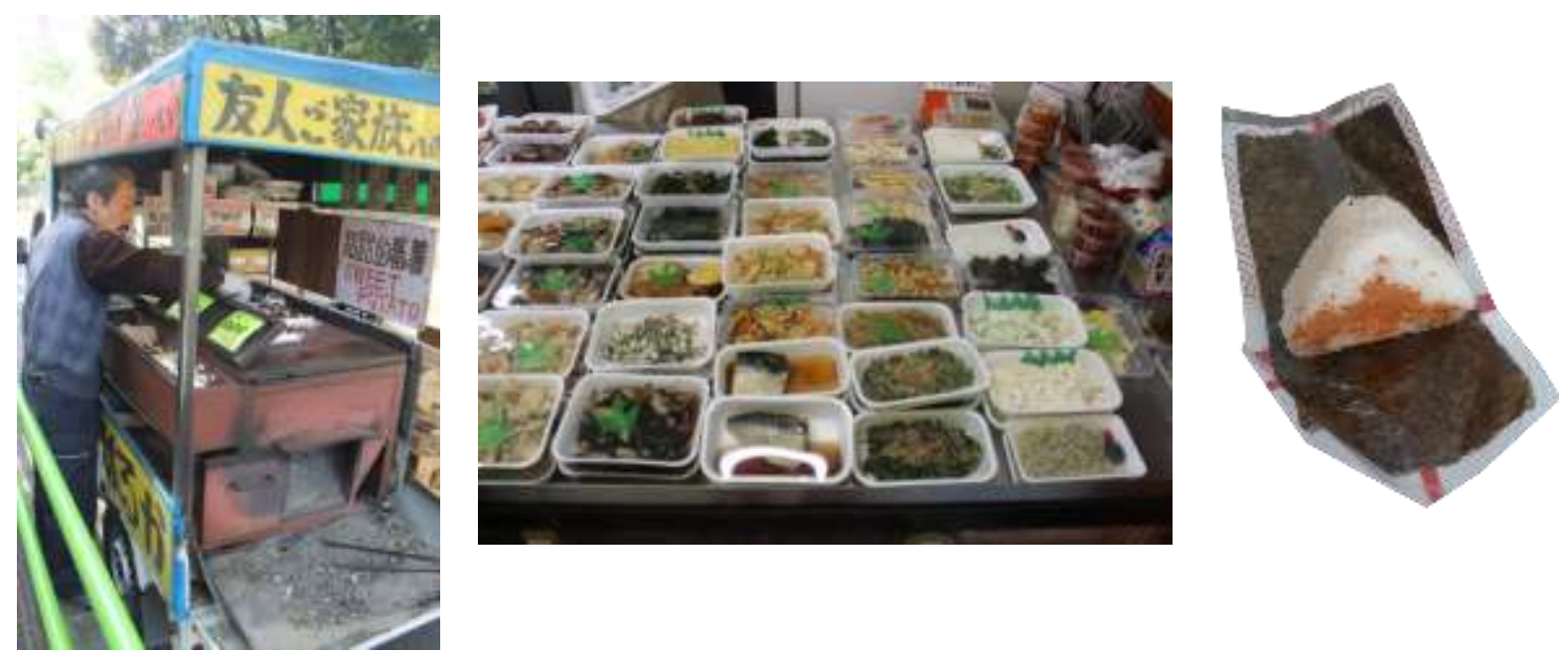

Fig. 2 (Left) Traditional Japanese sweet potato seller. (Center) Japanese food decorated with fish fin form made from green colored plastic.These food look more attractive. (Right) Japanese rice wrapped in seaweed and packed interesting and easy to eat. 


\section{Product Packaging Function}

The main function of a packaging is to keep products from dirt, clean, hygienic, and easy to carry or store. The raw material of a package must be in accordance with the functions, especially hygienic aspects. Another function of a packaging or a label is as a product identity that distinguishes one product from another. Prospective buyers easily recognize a product because it sees the shape of a package. For packaging to be more recognizable and more attractive, some packs are labeled or branded.

The selection of packaging raw materials on traditional food products is not just a wrapper, but also can create the scent. The Bacang product is wrapped in leaves Hanjuang because the leaves are wide in size and not easily torn and create special scents. The product Wajit or Dodol is packed with dried corn leaves to keep it from sticking; Lontong wrapped in banana leaves; and Ketupat wrapped in coconut leaves and create a distinctive and artistic shape. Some of these traditional foods have been replaced with plastic - for example Lontong for easy cooking and can make a large size. But it feels less good when compared with Lontong wrapped in banana leaves also do not have a fragrant. Though a fragrant food is important because it can stimulate appetite.

\section{CONCLUSION}

Culinary tourism in Bandung City has a significant impact on increasing waste volume. Much of the garbage can not be recycled, thus endangering both the environment and the human. The impact is caused by various factors, including the lack of infrastructure owned by the government of Bandung City, such as the limited number of garbage can or full garbage can rarely taken by officers. Another factor is the low participation of factory outlet entrepreneurs in providing hygiene facilities, street food vendors, and consumption patterns of tourists and people who prefer instant food than traditional food. In addition, law enforcement needs to be done in the implementation of garbage policy in Bandung City. Implementation of cleanliness and waste programs undertaken by the government of Bandung is less effective.PPP is one of the models in addressing public issues in some countries. Bandung City government needs to adopt the model because of garbageproblem is not just infrastructure but is the community and its lack of concern on cleanliness and environmental.

Therefore, sustainable tourism development program is one of the concepts to solve the problem of waste due to culinary tourism and develop the quality of tourist destinations. The above model can be implemented if all parties can participate. The purpose of the model is that tourist destinations can be saved from the negative impact of tourism industry, such as pollution or environmental damage.

Innovation is one of the efforts to face the competition of the tourism industry and in order to improve its quality. Innovation that needs to be done is innovation process and product to produce culinary product based on eco-friendly product concept. Most importantly it should be understood that innovation is not creating something new right but can modify or add something to an existing package.

One model of eco-friendly packaging design is to use natural raw materials such as leaves. The raw material is widely available in Indonesia and has added value such as unique shape, attractive, gives the flavor and taste of the product and cheap. Constraints in implementing the traditional packaging design for culinary products today is how to provide extrinsic value for consumers (tourists). Some consumers buy the product because it has a well-known brand, famous company is not the quality of its products. Therefore, the appearance of culinary packaging should attract and create prestige. 


\section{REFERENCES}

Alamsyah, Kamal.,Loupias, Henry, "Role of New Public Service Model in Developing Tourist Destination in Bandung City: A New Paradigm for Domestic Tourism Industry," In the Proceedings of ICMEB International Conference on Management Economic and Business, MercuBuana University, 55 (2018).

Atieno, Pamela.,Ochieng." Understanding Reliability and Validity in Qualitative Research. The Qualitative Report 8(4), 597-607 (2009).

Atilgan, Eda.,Akinci, Serkan., andAksoy, Safak.,"Mapping Service Quality in The Tourism Industry," Managing Service Quality 13 (5), 412-422 (2003).

Balalia, Elena.,Alina and Petrescu, Mariana., Roluca.,"The Involvement of the Public and Private Sector - Element with Influence on Travel and Tourism Demand During the Crisis Period,"Tourism and Hospitality Management17(2), 217-230 (2011).

Barbe, Topolansky., Federico., Triay, Honzales., and Magdalena., Haufele, Cornelio.,"The Competitiveness of The Uruguayan Rural Tourism Sector and Its Potential to Attract German Tourists,"Competitiveness Review 26(2), 166-187(2016).

Batat, Wided., and Prentovic, Sonja., "Towards Viral Systems Thinking: A Cross Cultural Study of Sustainable Tourism Ads,"Emerald Journal of Business4 (3/4), 529-546 (2014).

Bessant, John., and Tidd, Joe.,"Innovation and Entrepreneurship,2nd edition,” JohnWiley \& Sons, Ltd., 2011.

Bhuiyan, H., Shahjahan.,and Amagoh, Francis.,"Public Sector Reform in Kazakhstan: Issue and Perspectives,"International Journal of Public Sector Management 24(3), 227-249(2002).

Breakthrough Innovation and Economic Growth," World Intellectual Property, (2015).

Environmentally friendly, "https://en.wikipedia.org/wiki/Environmentally_friendlyRetrieved 05 March, 2018.

Eraqi, I., Mohammed., “Tourism Services Quality (TourServqual) in Egypt. The Viewpoints of External and Internal Customers,"Benchmarking: An International Journal 13 (4), 469-492 (2006).

Hall, Michael.,Campos, Sapata., and Jose., Maria.,"PublicAdministration and Tourism-International And Nordic Perspectives, “ Scandinavian Journal of Public Administration18 (1), 3-17 (2014).

Holden, Jeane.,"Principles of Entrepreneurship," U.S. Departement of State/Bureau of InternationalInformation Programs, 2007.

Kavoura, Androniki., and Stavrianeas, Aikaterini.,"The Importance of Social Media on Holiday Visitors' Choices - The Case of Athens, Greece,"Emerald Journal of Business 10 (3), 360374(2015).

Misrahi, Tiffany. (2017). South-East Asia's most tourism-friendly destinations,https://www.weforum.org/agenda/.../south-east-asia-s-most-tourism-friendlydestination.Retrieved 05 March, 2018. . (2011). The Changing Face of Innovation. Geneva. World Intellectual Organization. 
Thomas, Brychan., Miller, Christopher., and Murphy, Lyndon., "Innovation and Small Business, Volume 1, $1^{\text {st }}$ edition," Bookboon.com., 2011.

Tidd, Joe and Bessant, John.,“ManagingInnovation, 5th edition,” John Wiley \&Sons, Ltd., 2013.

Yuzbasioglu, Nedim.,Celik,Pinar., and Topsakal, Yunus., " A Research Innovation in Small Business and Medium-sized Enterprises in Tourism Industry: Case of Travel Agencies Operating in Antalya," In the Proceeding of $10^{\text {th }}$ International Strategic Management Conference, 735-743, (2014).

What Does Eco-Friendly Means.http://homeguides.sfgate.com/ecofriendly-mean78718.htmlRetrieved 05 March, 2018. 